\title{
Hydrocarbon Potential of Two Coastal Basins (Cameroon)
}

\author{
Jean Jacques Nguimbous-Kouoh ${ }^{1}$, Jacques Tchutchoua1, Simon Ngos III', \\ Theophile Ndougsa Mbarga ${ }^{2}$, Eliezer Manguelle-Dicoum ${ }^{3}$
}

${ }^{1}$ Department of Mines, Petroleum, Gas and Water Resources Exploration, Faculty of Mines and Petroleum Industries, University of Maroua, Maroua, Cameroon

${ }^{2}$ Department of Physics, Advanced Teacher's Training College, University of Yaoundé 1, Yaoundé, Cameroon

${ }^{3}$ Department of Physics, Faculty of Science, University of Yaoundé I, Yaoundé, Cameroon

Email: *nguimbouskouoh@yahoo.fr

How to cite this paper: Nguimbous-Kouoh, J.J., Tchutchoua, J., Ngos III, S., Mbarga, T.N. and Manguelle-Dicoum, E. (2018) Hydrocarbon Potential of Two Coastal Basins (Cameroon). International Journal of Geosciences, 9, 131-147. https://doi.org/10.4236/ijg.2018.92009

Received: January 18, 2018

Accepted: February 25, 2018

Published: February 28, 2018

Copyright ( 2018 by authors and Scientific Research Publishing Inc. This work is licensed under the Creative Commons Attribution International License (CC BY 4.0).

http://creativecommons.org/licenses/by/4.0/

\begin{abstract}
The problem related to the occurrence of oil accumulations in a sedimentary basin requires knowledge of the different geological structures present in this basin. The aim of this article is to show that the geological structure of sedimentary basins has an impact on the generation of oil accumulations. The case of Cameroon's coastal basins has been studied: the Douala/Kribi-Campo basin (DKC) and the Rio Del Rey basin (RDR), which are producing basins in Cameroon. The work carried out has enabled to classify the DKC and RDR basins as passive margin basins. The lithology and geological structures present in the Douala/Kribi-Campo basin suggest the existence of source rocks (RM-1, RM-2, RM-3, RM-4 and RM-5), seal rocks (Mundeck clay, Logbabaclay...), stratigraphic, structural and mixed traps; the best oil potential is identified in its eastern part. On the other hand, the sandy levels are abundant, clean, and thick with a great porosity, which makes them excellent hydrocarbon reservoirs. In the Rio Del Rey basin, the lithology and geological structures present suggest the occurrence of source rocks (Akata clay and Agbada base clay), seal rocks (Akata clay) and multilayered reservoir rocks sandy or silty Agbada Formation and the freshwater sands of the Benin Formation. Unlike the Douala/Kribi-Campo basin, the best oil potential in the Rio Del Rey Basin lies in the center, in the so-called "deltaic alternation" formations dated from the late Miocene to the Pliocene.
\end{abstract}

\section{Keywords}

Sedimentary Basin, Geological Structure, Source Rock, Reservoir Rock, Oil Accumulation 


\section{Introduction}

In Cameroon, along the Atlantic margin, two sedimentary basins are separated by the Cameroon volcanic line (CVL): the Rio Del Rey Basin representing the south-eastern extension of the Niger-Delta and the Douala/Kribi-Campo Basin, epicontinental depression passive margin, born from the opening of the South Atlantic [1]. These two basins extend along the Gulf of Guinea and belong to the West African saltwater system group, according to their structural characteristics, in the Central West Coast Province extending from Cameroon to Namibia [2]. These sedimentary basins are portions of basements covered by sediments. Their bowl shape promotes a high concentration of detrital debris, chemical and organic origins deposited in the form of layers. The arrangement of these layers related to stresses and tectonic movements affect the basins and condition their morphology as well as their geological structures [3] [4]. The sediments of organic origin in these basins, deposited under favorable conditions to their conservation have over the years undergone transformations related to the changes of temperature and pressure which led to the formation of hydrocarbons. These hydrocarbons, after their migration and accumulation in porous and permeable reservoirs, will constitute a set called oil accumulations [3] [4]. In this article, we want to show that the geological structures of a sedimentary basin participate in the genesis of oil accumulations. We will start from the following hypotheses: hydrocarbons do not accumulate in the environments where they originate; the pathway between these different environments are of particular interest; the impact of the geological structure in the genesis of oil accumulations includes, the processes of formation of oil in the source rock, the migration in the reservoir rock and the creation of the seal rocks.

The oil explorations carried out in the Douala/Kribi-Campo (DKC) and Rio Del Rey (RDR) basins will highlight the presence or absence of geological structures. We will first present the geological context of the two basins, then the different types of geological structures in general and demonstrate how these geological structures participate in the formation of oil accumulations. Finally, we will make a structural interpretation of the RKC and RDR basins.

\section{Geologic and Tectonic Setting of the Douala/Kribi-Campo (DKC) and Rio del Rey (RDR) Sedimentary Basins}

The geological history of coastal sedimentary basins (Figure 1) begins in the early Cretaceous by the breakout marking the separation of South America and Africa (Figure 2). The filling of basins begin during this initial rift phase with the establishment of the first deposits of the Lower Mundeck Formation [5] [6]. This filling begins at the Barremian in the Kribi-Campo sub-basin and at the Aptian in the Douala sub-basin [6] [7]. The continental deposits of Lower Mundeck consist of conglomerate, sandstone (base sandstone), dark gray shale, rich organic matter marl and thin limestone beds [8]. At the end of the Aptian, during a period of transition, the first marine incursions develop salt series that will 


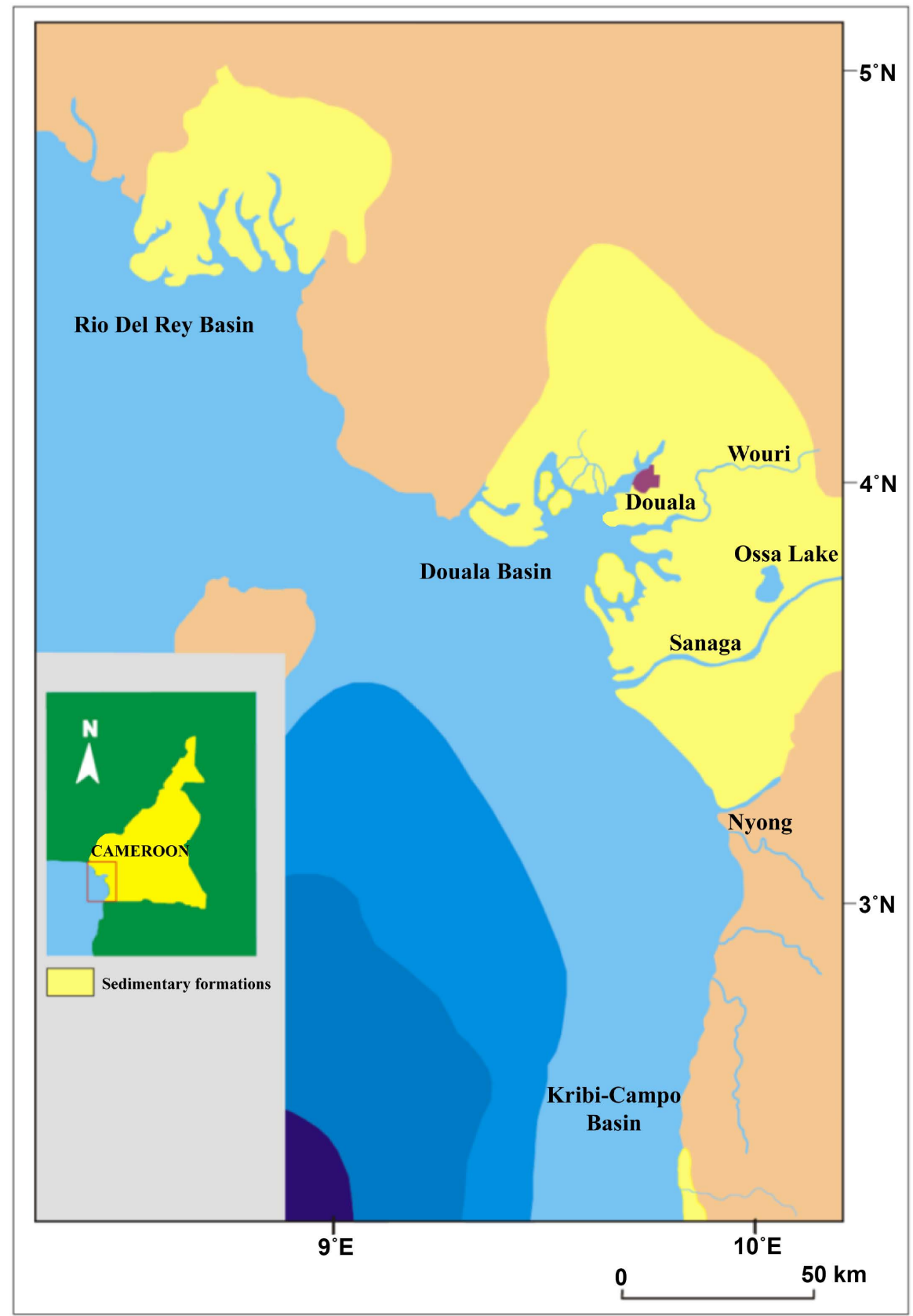

Figure 1. Location map of the Douala/Kribi-Campo and Rio Del Rey basins [1].

accumulate from Cameroon to Angola [7]. At this transition phase follows three separation intervals from the Albian to the Present during which a passive margin was formed by accumulation of unconformity sedimentary deposits, separated by cuts due to orogenesis phase [8] [9].

In the Albian, the large marine transgression of the Drift I phase (Figure 2) leads to the formation of upper Mundeck layers, sandstone, argillite, organic clay and carbonate. This succession generally ends with the "discordance of the Cenomanian", a consequence of the beginning of a regression continuing in the Turonian [9]. 


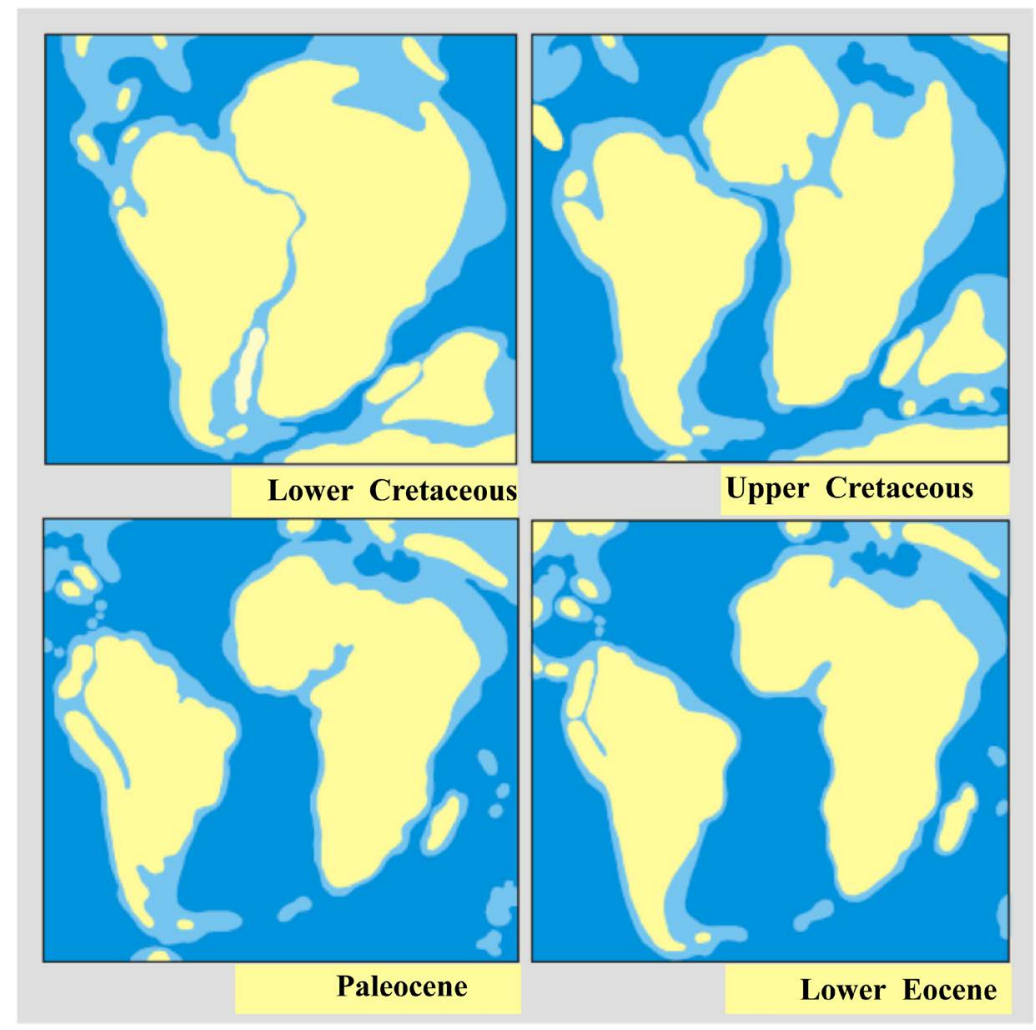

Figure 2. Paleogeography of the South Atlantic (Cretaceous-Lower Tertiary) from: [8].

The Drift II phase (Figure 2), related to the Santonic tectonic episode, is separated from Phase I (Drift I) by a discontinuity resulting from this event. As a result of the latter, already begins in Santonian and continues in the lower Campanian the deposit of the Logbadjek Formation, made of microconglomerate, sand, medium to coarse sandstone and rare intercalations limestone and clay. This follows, in the Upper Campanian and Maastrichtian, the thick Formation of Logbaba formed of marine sediments of deep water predominantly clay. These sediments consist of fossiliferous argillite with sandstone and sand levels ([1] [5]).

In all the basins of West Africa, the Cretaceous-Tertiary passage is underlined by the gap of the Maastrichtian terminal and the Danian. In the Douala Basin, tertiary sedimentation begins with the deposition of the Nkapa Formation by simple subsidence of the passive margin. This Paleocene-Early Eocene age consists of bedded clay, argillite, fine-to-coarse friable sandstone, silt, sand lentils, and dolomite ([1] [10] [11]).

Sedimentation is abruptly halted during the Eocene by the major mid-Tertiary uplift episode, creating the large stratigraphic gap of the Late Eocene-Lower Oligocene. The Souellaba Formation, Oligo-Miocene, produced from a subsidence and beginning at the same time as the Drift III phase (Figure 2) at the end of the Oligocene [1] [8] [10] [11] rests unconformably on the Formation from Nkapa; it is characterized by marls, sandstones, silts and clays with interstratified 
sand lenses and occasional shell limestones. After a last stratigraphic gap at the end of the Miocene, the Cenozoic series ends with the Formations of Matanda (Pliocene) and Wouri (Pleistocene) made of fine to coarse sand, variegated clay and volcanic tuff.

\subsection{The Fracturing of the American-African Bloc at Aptien-Albien}

Continental fracturing and rifting of the Aptian-Albian (Figure 3) are facilitated and oriented by the reactivation of large fractures dating from the pan-African orogeny ( -650 to $-450 \mathrm{MA}$ ), including the Pernambuco-Tiko-Adamaoua fracture system which separates the future passive margin into two areas, the future Rio Del Rey (RDR) basin in the north and the future Douala/Kribi-Campo basin in the south. It is on this same set of fractures that will settle, at the end of the Cretaceous, Douala Kribi Campo basin [4] [6] [11] [12].

\subsection{Passive Margin Mechanisms during the Pre-Rift, Syn-Rift Phase}

During a continental fracturing of this type gradually leading to the opening of an ocean (Figure 3), the faults, so-called listriques, are curved in depth. This particular geometry entails the tilting of the roof of the blocks during the general stretching and an uneven sedimentary filling above this roof (sedimentation in "fan"). Thus, in the pre-rift phase listric fractures, in the syn-rift phase, a stretching effect and in syn-rift phase, then post-rift, a stop of stretching [8] [11] [12] [13] [14].

\section{Different Types of Geologic Structures and Hydrocarbon Generation}

\subsection{Different Types of Geologic Structures}

Structural geology is the study of the ways in which rocks or sediments are arranged and deformed on the earth. It involves all three rock types: igneous,

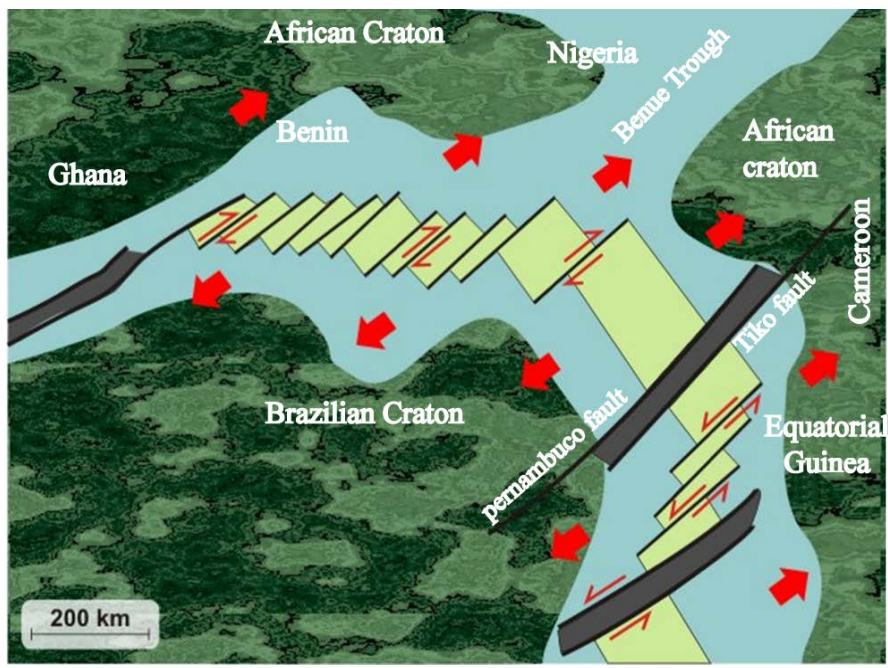

Figure 3. The fracturing of the American-African bloc at Aptien-Albien. 
sedimentary, and metamorphic [3] [4] [15] [16]. In this part, we will describe the geological structures that are often encountered in structural geology: folded structures, faulted structures, monoclinal structures and tabular structures.

- The folded structures result from flexible deformation and are found exclusively in sedimentary rocks. A fold combines two parts, one anticlinal and the other synclinal. Crossing through a fold, the following elements are presented: the hinges (ca and Cs), the blanks (right flank and left flank), the fold axis, the height, the waving wavelength.

- Flaulted structures are breaks affecting a lot. Faults are structures related to brittle tectonics that can affect all rocks. Between a fault and a diaclase, the distinction is made by the relative displacement of the rocky compartments located on both sides of the invoice plan. The fault plane, the fault mirror, the lips and the rejection are the elements that make up a faulted structure.

- Monoclinal structures are layers that form an inclined plate. These provisions are not strongly inclined. It has a dip of less than or equal to $40^{\circ}$.

- The tabular structures are almost horizontal layers with no or low dip of $15^{\circ}$.

\subsection{Hydrocarbon Generation}

The sediments that originate from continental erosion contain a certain proportion of organic matter that is transported and deposited in the oceanic and lacustrine basins, together with the mineral particles. To this terrigenous organic matter is added that coming from the biomass of the oceanic basin or lacustrine itself, that is to say the organic remains resulting from the destruction of algae, bacteria and plankton ([17] [18] [19] [20]). The whole constitute "the sedimentary organic matter" which, during its burial, under the influence of temperature, deteriorates progressively while losing initially oxygenated constituents in the form of $\mathrm{CO}_{2}$ and $\mathrm{H}_{2} \mathrm{O}$, it is the stage of "Diagenesis" stage during which the free oxygen contained in the seawater is rapidly consumed by the oxygen of a part of the organic matter, this causes the conditions in the sediments to become rapidly anoxic that is to say without oxygen and, we can also speak of "anaerobic environment" [17] [18] [21] [22] [23]. Organic matter composed of carbon, hydrogen, oxygen and nitrogen in anaerobic media that do not need free $\mathrm{O}_{2}$. For their metabolism, these anaerobic bacteria will draw oxygen and nitrogen in the organic molecules to leave in latter only hydrogen and carbon: it is the "biochemical degradation" of organic matter. Carbon and hydrogen will unite or associate to form new molecules essentially composed of these two elements and called hydrocarbons or carbides of oxygen [23] [24] [25]. One of the first molecules that is formed is "methane" $\left(\mathrm{CH}_{4}\right)$ (natural gas), which is a biogenic gas because it is derived from biochemical degradation, this is the origin of natural gas. As sediments pile up on ocean or lake floors, the burial becomes very important, the hydrocarbon molecules brought to higher temperatures and pressures of higher and higher, become very complex. Degradations then pass from biochemicals governed by bacteria, thermal (governed by the rise in tempera- 
ture). This is the stage of "catagenesis" whose beginning is between $60^{\circ} \mathrm{C}$ and $120^{\circ} \mathrm{C}$ (depending on the local geothermal gradient). For a depth of 1500 to 4000 $\mathrm{m}$, the main stage of oil formation (crude oil) and light HC. The next step, corresponding to higher temperatures and pressures, and a very advanced evolution called "metagenesis", during which the formation of "dry gas" (methane) by cracking of previously formed $\mathrm{HC}$ and residual kerogen: this is the late methane [17] [18] [19] [20].

\section{Data Origin}

The data used come from: drilling cuttings made by oil companies in the Douala/Kribi-Campo and Rio Del Rey basins; sampling taken from the surveys sequences; end-of-survey reports describing the logging signatures, in particular of gamma ray, and the lithology of the formations of each of the wells studied; tables describing the stratigraphy and elements of the two petroleum systems. The different sequences found in the two basins were also studied.

\section{Structural Interpretation of the DKC and RDR Basins}

\subsection{Douala/Kribi-Campo Basin}

Figure 4 represents the structural cross section of the DKC basin deduced from the different studies that have been carried out over the Douala/Kribi-Campo basin [1]. The geologic cross section is a view of a vertical slice of the earth. A cross-sectional view can reveal details of a structure not visible in map view, such as cross bedding ([3] [4] [15]).

The DKC basin covers a total area of almost $19000 \mathrm{~km}^{2}$, of which $7000 \mathrm{~km}^{2}$ is the onshore part. It is generally subdivided into two sub-basins: the sub-basin of Douala which is in the northern part and the sub-basin of Kribi-Campo in the southern part. It has an important extension towards the offshore of the Precambrian basement between the sub-basins of Douala and Campo. This pedestal, carved out of horsts and grabens, is sub-outcropping in the inner part of the plateau, and then covered towards the open by slightly wrinkled layers dated from the Upper Cretaceous and the Paleogene. In the axis of the Douala basin, there is a succession of prograding facies from the Miocene up to the Pleistocene that are separated by sedimentary discontinuities and angular discrepancies [11].

Structurally, the two sub-basins are distinguished on both sides of the mouth of the Nyong River: the sub-basin of Douala in the North and the sub-basin of Kribi-Campo in the South. The Douala sub-basin is characterized by a semi-graben structure and sedimentary deposits up to $6000 \mathrm{~m}$ thick (Figure 4). Channels, fans and turbiditic piles in the Upper Cretaceous and the Tertiary are found there, with a deeply buried syn-rift sequence. Overall, tectonics is weak in the sub-basin of Kribi-Campo meanwhile, it is characterized by: A structural extension towards the East; An uprising of Kribi-Campo which borders the coast; A basement and lower Cretaceous deposits compartmentalized in fault blocks inclined to the west; the upper and tertiary cretaceous deposits on the western 


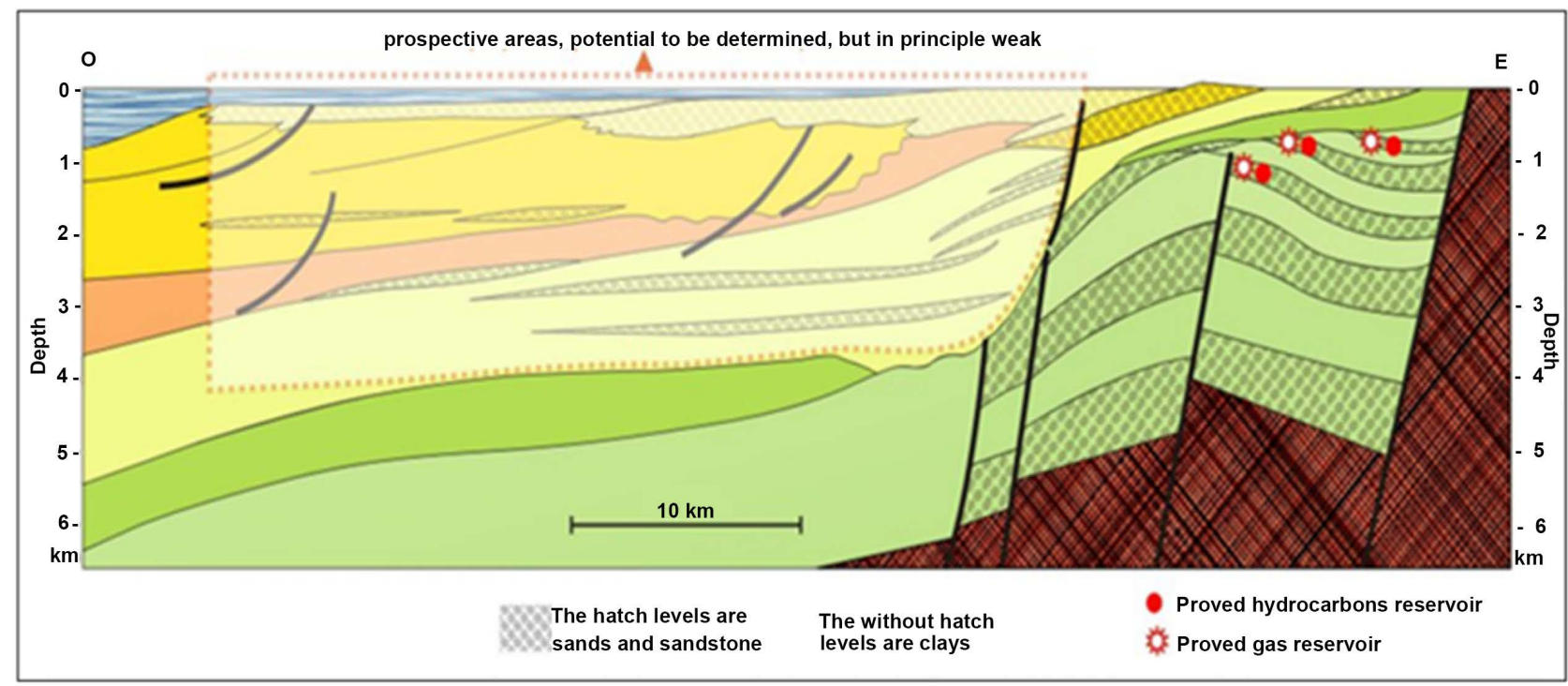

Figure 4. Structural cross section of the Douala/Kribi-Campo basin showing rock stratigraphy and fault.

flank are affected by roll-over anticlines associated with listric faults located along the continental slope; A localized halocinese and associated structures, affecting the Upper Cretaceous in Kribi offshore.

The stratigraphy of the Douala/Kribi-Campo basin (Tables 1-3) generally presents six sequences: Wouri, Matanda, Souellaba, N'kapa, Logbaba and Mundeck; which are composed of several horizons. Knowing the regional geology and based on the concept of sequential stratigraphy, a relationship between the stratigraphy and the elements of the petroleum system of the different formations could be realized [22] [26].

In the Douala/Kribi-Campo basin, the best oil potential is identified in its eastern part, mainly in apto-albian deposits, syn-rifts, covering the tilted blocks. The few geochemical analysis performed on source rocks indicate: a mixed continental and marine origin for organic matter residues, the TOC up to $5 \%$; S2 up to $11.2 \mathrm{mg} \mathrm{HC} / \mathrm{g}$ rock; a good maturity of the source rocks is from 1500 meters deep if the temperature conditions are adequate.

In general, Tables 1-3 show that the lithologies and geological structures present in the Douala/Kribi-Campo basin suggest the existence of source rocks (RM-1, RM-2, RM-3, RM-4 and RM-5), covered rocks (Mundeck clay, Logbaba clay...), stratigraphic, structural and mixed traps; the best oil potential is identified in its eastern part [1]. On the other hand, the sandy levels are numerous, clean, thick and of great porosity, which makes them excellent hydrocarbon reservoirs.

\subsection{Rio Del Rey Basin}

Figure 5 shows the structural cross section of the Rio Del Rey Basin deduced from the different studies that have been conducted over (RDR). Its southern margin is a divergent margin whose formation is related to the opening of the 


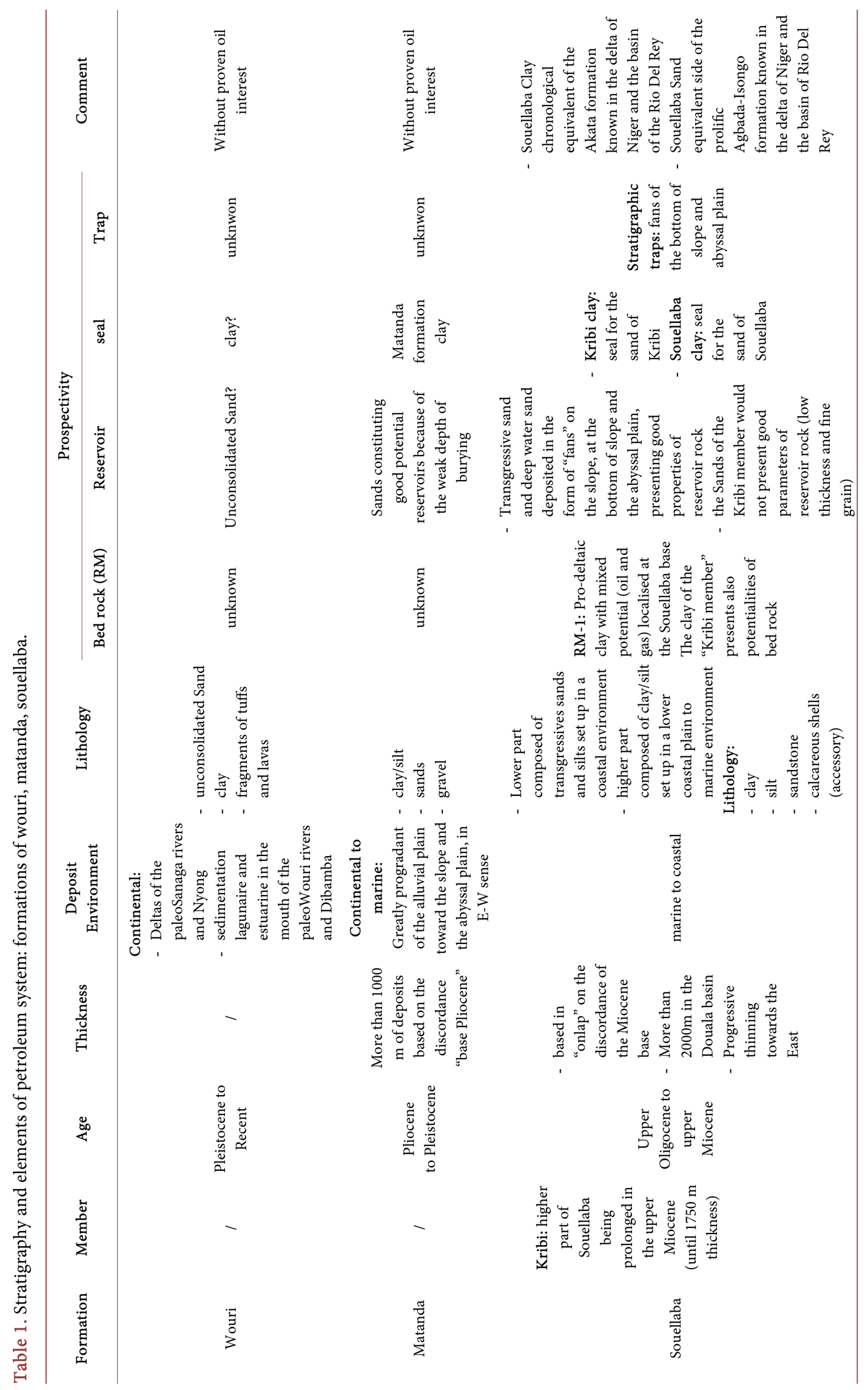




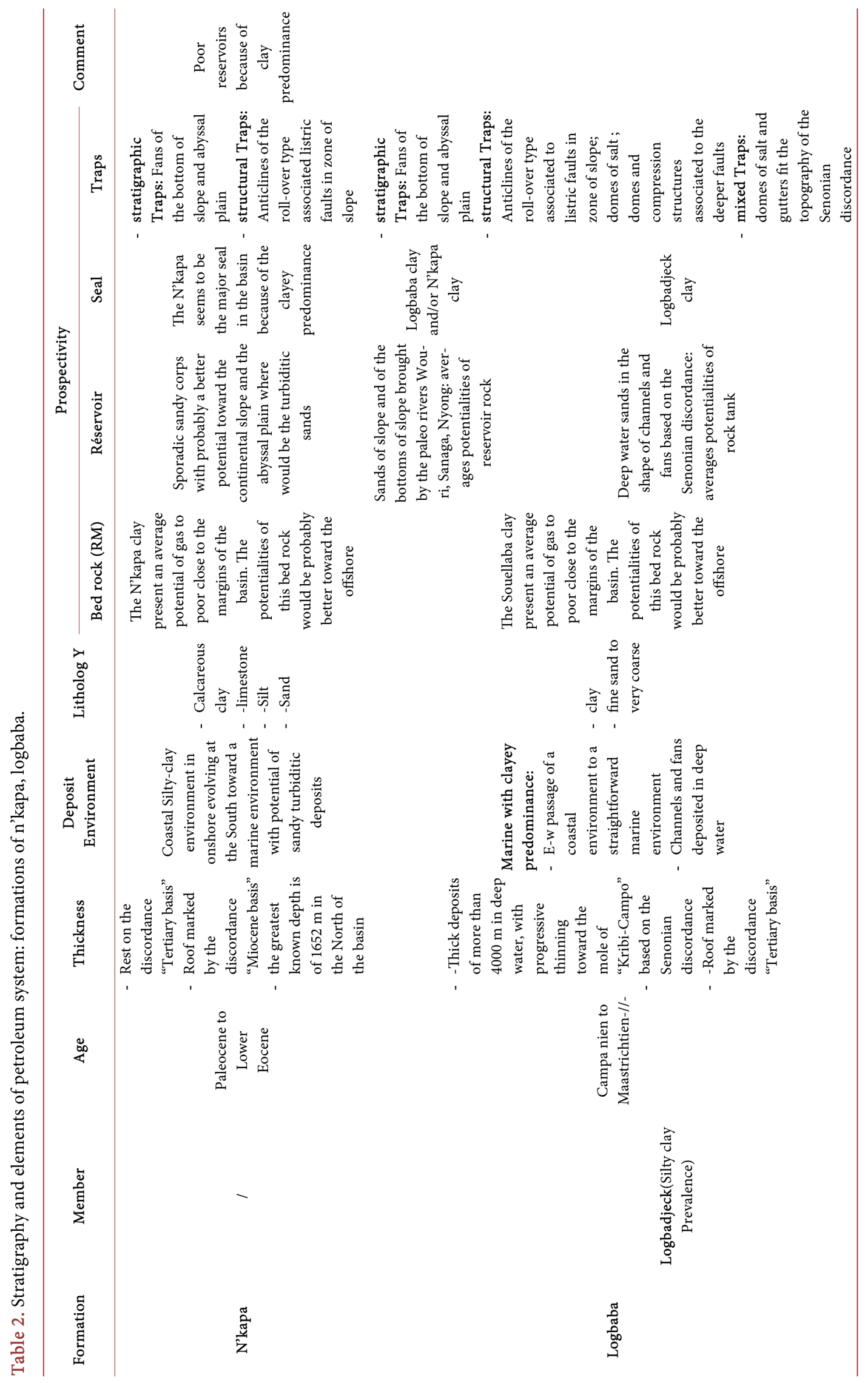




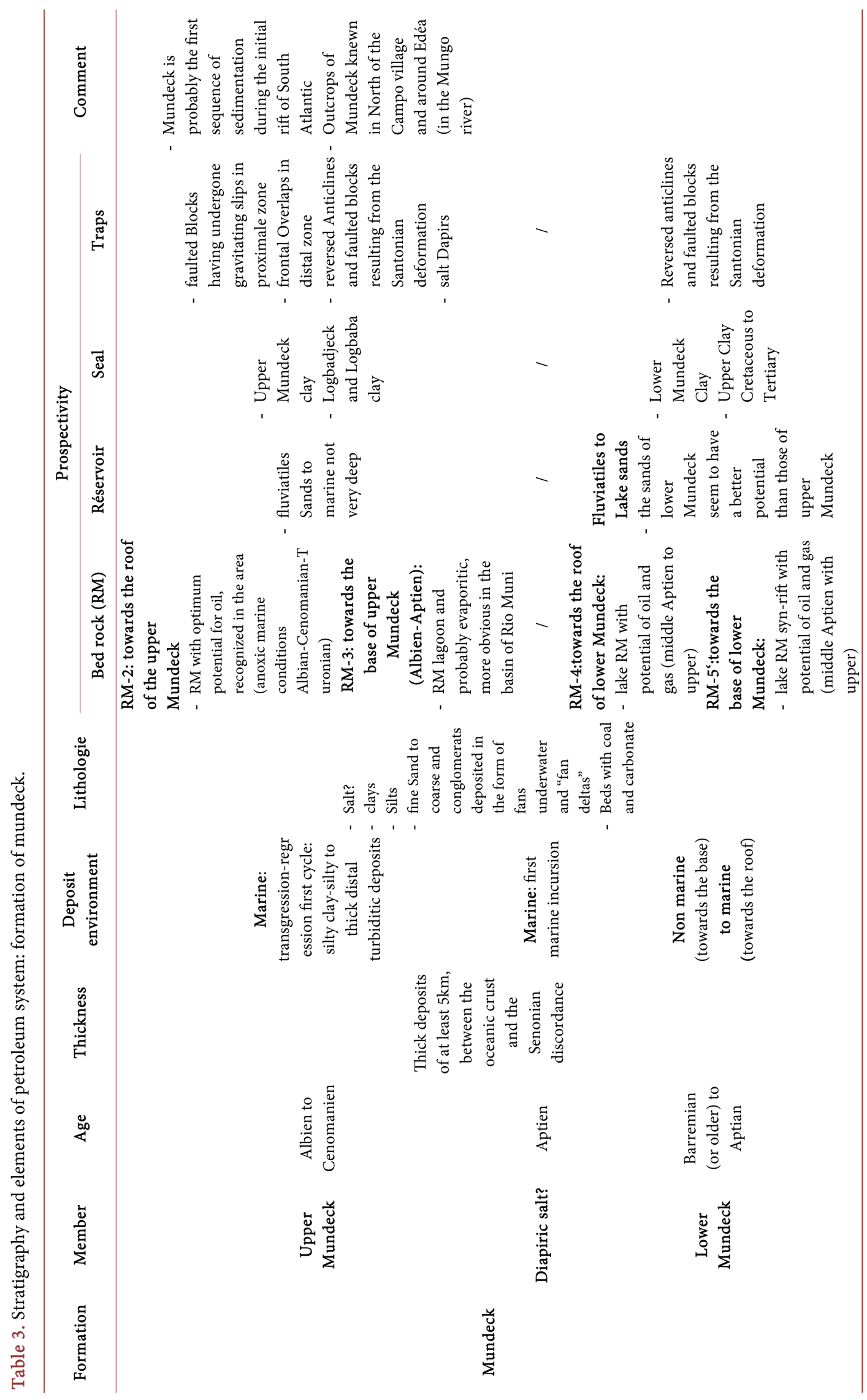




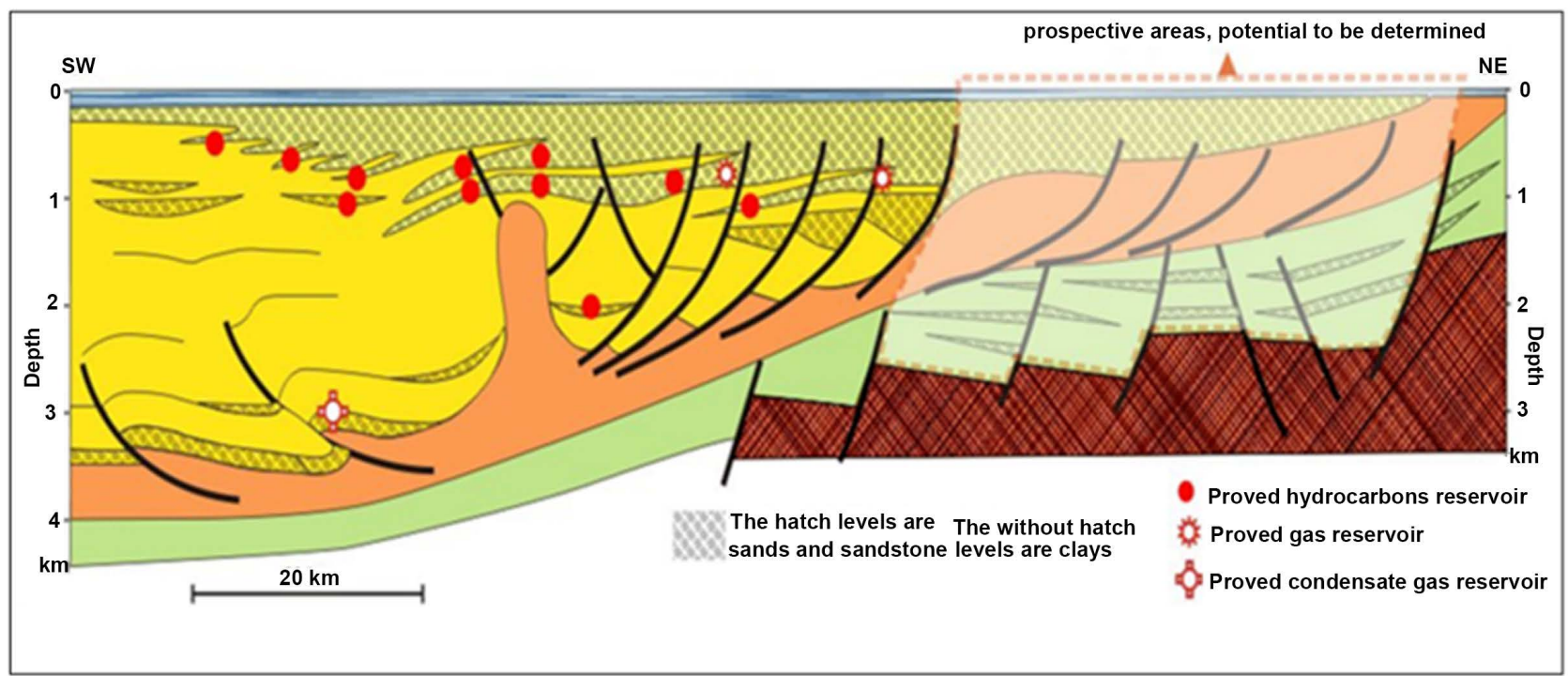

Figure 5. Structural cross section across Rio Del Rey Basin showing rock stratigraphy and fault.

Table 4. Stratigraphy and elements of petroleum system: formation of benin.

\begin{tabular}{|c|c|c|c|c|c|c|c|c|c|c|}
\hline \multirow{2}{*}{ Formation } & \multirow{2}{*}{ Member } & \multirow{2}{*}{ Age } & \multirow{2}{*}{ Thickness } & \multirow{2}{*}{ Deposit Environment } & \multirow{2}{*}{ Lithology } & \multicolumn{4}{|c|}{ Prospectivity } & \multirow{2}{*}{ Comment } \\
\hline & & & & & & Bed rock & Reservoir & seal & trap & \\
\hline BENIN & I & $\begin{array}{l}\text { Pliocene } \\
\text { to recent }\end{array}$ & $\begin{array}{c}450 \text { to } 1200 \\
\mathrm{~m} \text { in the } \\
\text { whole } \\
\text { basin }\end{array}$ & $\begin{array}{l}\text { Continental (higher } \\
\text { deltaic plain): } \\
\text { Thick sand banks with } \\
\text { some rare clayey } \\
\text { intercalations especially } \\
\text { at the base (which is } \\
\text { marked by the } \\
\text { appearance of the first } \\
\text { levels with marine } \\
\text { animal-life) }\end{array}$ & $\begin{array}{l}>\text { Sand with } \\
\text { coarse grain } \\
\text { and badly } \\
\text { classified } \\
>\text { Clay }\end{array}$ & Unknown & $\begin{array}{c}\text { Sand } \\
\text { invaded } \\
\text { soft water }\end{array}$ & Unknown & unknown & $\begin{array}{c}\text { Without } \\
\text { proven oil } \\
\text { interest }\end{array}$ \\
\hline
\end{tabular}

South Atlantic, between the African and South American continents during the Albo-Aptian. This opening was made by an initial phase of rifting marked by extensive fracturing of the basement and a rift phase mainly dominated by growth faults ([16]. This margin corresponds to the eastern end of the Niger Delta established during the Paleocene-Eocene. It is limited to the East by the major fracture zone of Pernambuco-Tiko-Adamaoua, a veritable hinge of the margins of the central Atlantic where the gigantic volcano of Mount Cameroon would be injected later.

The structure of the basin is characterized by a dense network of syn-sedimentary and post-sedimentary faults more or less parallel to the coast with numerous compensations or roll-over anticlines that are characteristics of the deltaic provinces and have good structural closures favorable to the accumulation of hydrocarbons [17]. There are also clay domes and wrinkles succeeding each other from East to West and elongated North-South: they result from the continuous vertical compression of the undercompacted clays, plastics and 


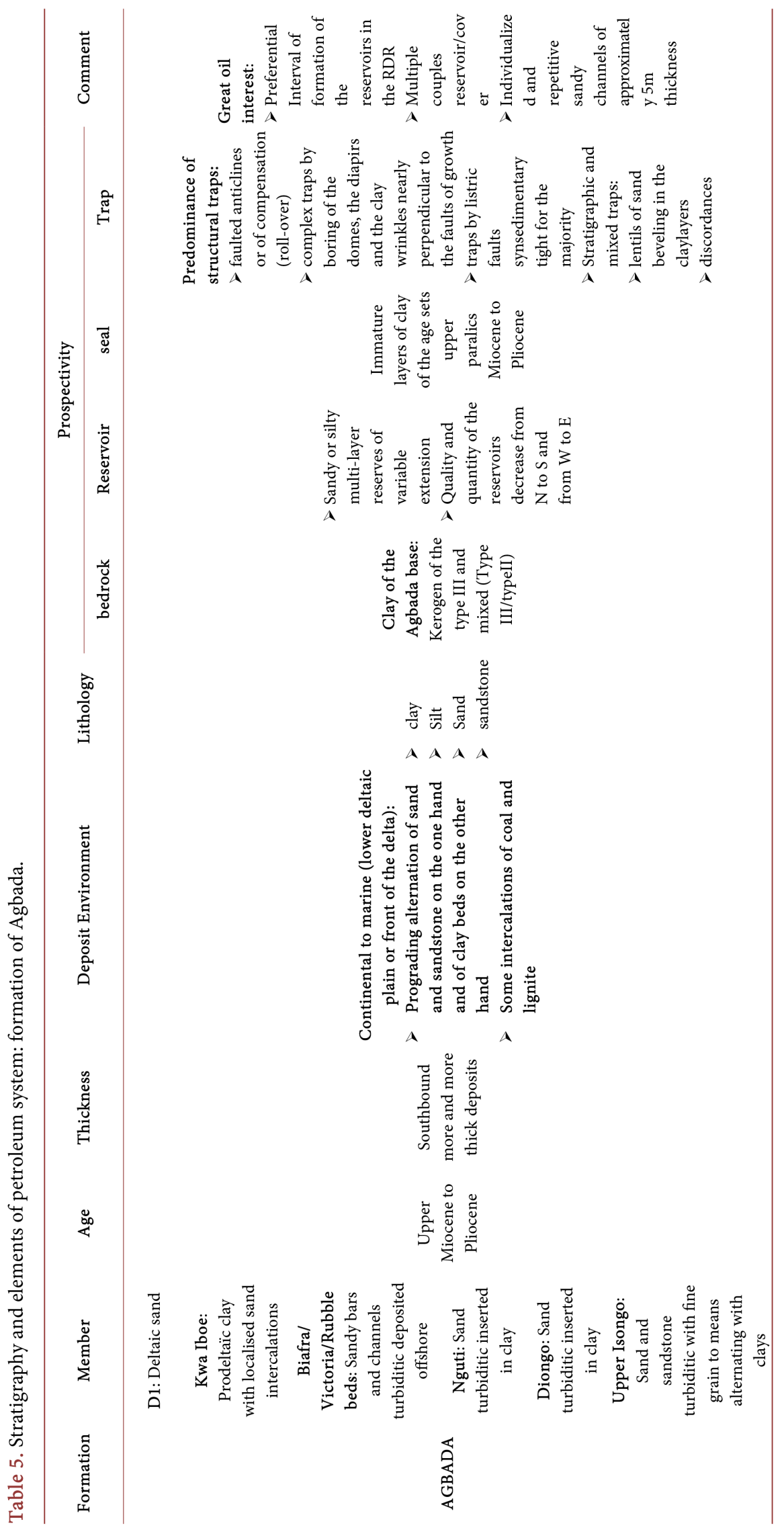




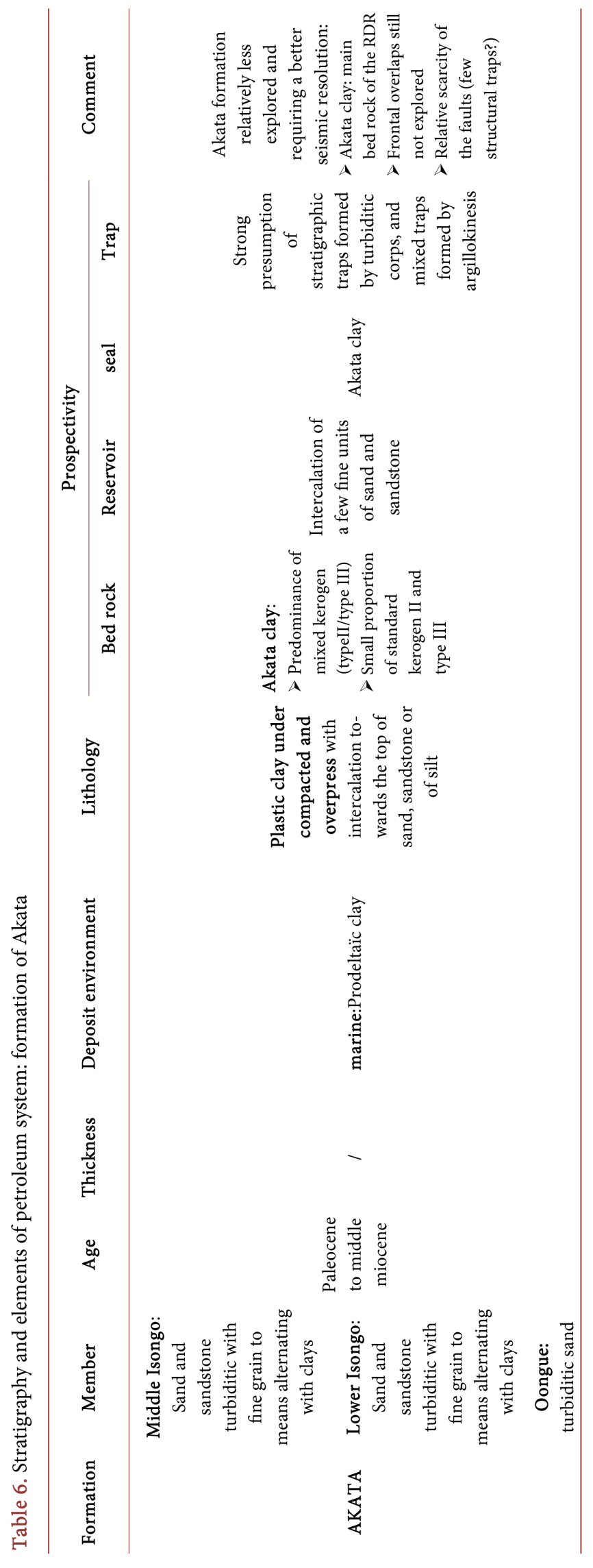


pressed from the Akata formation. They provide the province with structures that are conducive to the accumulation of hydrocarbons.

Unlike the Douala Basin, the best oil potential of the Rio Del Rey Basin is located in the center, in the so-called "deltaic alternation" formations dated from the late Miocene to the Pliocene (about 5 billion years of deposits). These sediments show alternating deltaic sandy levels and clays. The folding of these formations suggests the existence of potential structural stratigraphic traps. The presence of traps in the side of wrinkles is also proven [1]. On the other hand, intensely fractured clay wrinkles facilitate the migration of hydrocarbons to potential traps. Organic matter has a clearer marine origin. The maturity of the source rocks is reached from 3000 meters deep, and the main reservoirs discovered are between 1000 and 2000 meters deep.

The general stratigraphy of the Rio Del Rey basins is similar to that of the Niger delta (Tables 4-6). It is marked by three main formations [8]: the formation of benin rich in fluvio-deltaic sand; the Paleocene Agbada Formation consists of deep clay deposits; Akata formation of the upper Miocene consists of clays and silts.

\section{Conclusion}

In this article, we wanted to show that the geological structure of a basin participates in the formation of oil deposits. It appears that geological structures play a key role in the formation of an oil field. For this, exceptional conditions are required: the presence of source rocks, porous and permeable reservoir rocks and impermeable rocks used as seals, tectonic or stratigraphic structures which can constitute traps, for its emplacement. In the Douala/Kribi-Campo and Rio Del Rey basins, the presence of source rocks, anticlinal structures, faults, is favorable for the trapping of hydrocarbons after migration and reservoirs which are mostly sandy have been proved explaining the existence of oil fields.

\section{Acknowledgements}

The authors thank the IRGM (Institute of Geological and Mining Research) and SNH (National Hydrocarbons Company) for permission to use the data set of this article.

\section{References}

[1] SNH (2005) Synthèse sur le Bassin du Rio Del Rey et sur le bassin de Douala/Kribi-Campo. Rapport Interne, 14 p.

[2] Brownfield, M.E. and Charpentier, R.R. (2006) Geology and Total Petroleum Systems of the West-Central Coastal Province (7203), West Africa. U.S. Geolodical Survey Bulletin, 2207-B, 52.

[3] Subrahmanyam, V., Krishna, K.S., Murthy, G.P.S., Gopala Rao, D., Ramana, M.V. and Gangadhara Rao, M. (1994) Structural Interpretation of the Konkan Basin, Southwestern Continental Margin of India, Based on Magnetic and Bathymetric Data. Geo-Marine Letters, 14, 10-18. https://doi.org/10.1007/BF01204466 
[4] Morley, C.K. (1995) Developments in the Structural Geology of Rifts over the Last Decade and Their Impact on Hydrocarbon Exploration. Geological Society, 80, 1-32. https://doi.org/10.1144/GSL.SP.1995.080.01.01

[5] Regnoult, J.M. (1986) Synthèse Géologique du Cameroun. Ministère des Mines et de l'Energie, Yaoundé, $119 \mathrm{p}$.

[6] Nguene, F.R., Tamfu, S. Loule, J.P. and Ngassa, C. (1992) Paleoevironments of the Douala and Kribi-Campo Sub-Basins in Cameroon, West Africa. In: Curnelle, R. Ed., Géologie Africaine, Bulletin du Centre de Recherche Exploration Production Elf-Aquitaine, Memoire, 13, 129-139.

[7] Tamfu, S.F., Batupe, M., Pauken, R.J. and Boatwright, D.C. (1995) Geological Setting, Stratigraphy and Hydrocarbon Habitat of the Douala Basin, Cameroon. American. Association. Petrolum. Geology. Bulletin, 79, 95.

[8] Ntamak-Nida, M.J., Bourquin, S., Makong, J.C., Baudin, F, Mpesse, J.E., Ngouem, C.I., Komhuem, P.B. and Abolo, G.M. (2010) Sedimentology and Sequence Stratigraphy from Outcrops of the Kribi-Campo Sub-Basin: Lower Mundeck Formation (Lower Cretaceous, Southern Cameroon). Journal of AfricanEarth Sciences, 58, 1-18. https://doi.org/10.1016/j.jafrearsci.2010.01.004

[9] Giresse, P. (1990) Esquisse géologique de l'Afrique centrale occidentale. In: Paysages quaternaires de l'Afrique centrale occidentale. ORSTOM, horizon.documentation.ird, 15-19.

[10] Batupe, M. (1996) Les aspects de l'évolution stratigraphique du bassin de Douala, Cameroun. In: Géologie Africaine. Editions Elf-Aquitaine.

[11] Lawrence, S.R., Munday, S. and Bray, R. (2002) Regional Geology and Geophysics of the Eastern Gulf of Guinea (Niger Delta to Rio Muni). The Leading Edge, 21, 1112-1117. https://doi.org/10.1190/1.1523752

[12] Dumort, J.C. (1968) Note Explicative sur la feuille Douala-Ouest. Carte Géologique de reconnaissance (1/500000). Direction des Mines et de la Géologie du Cameroun, Cameroun, 69.

[13] Aloisi, J.C., Benkhelil, J., Giresse, P. and Ggueutchoua, G. (1995) Étude sismique haute résolution du précontinent sud-camerounais; analyse structurale et faciologique. Comptes Rendus de l'Académie des Sciences (Sous Presse), 10, 15.

[14] Mbesse, C.O. (2014) La limite paleocène-Eocène dans le bassin de Douala Biostratigraphie et essaie de reconstitution des paléoenvironnements. $\mathrm{PhD}$ Thesis, University of Yaounde 1, Cameroon.

[15] Biswas, S.K. (1987) Regional Tectonic Framework, Structure and Evolution of the Western Marginal Basins of India. Tectonophysics, 135, 302-327. https://doi.org/10.1016/0040-1951(87)90115-6

[16] Campos Neto, M. da C., Cioffi, C.R., Moraes, R., da Motta, R.G., Siga Jr., O. and Basei, M.A.S. (2010) Structural and Metamorphic Control on the Exhumation of High-P Granulites: The Carvalhos Klippe Example, from the Oriental Andrelândia Nappe System, Southern Portion of the Brasília Orogen, Brazil. Precambrian Research, 180, 125-142.

[17] Talbot, M.R., Morley, C.K., Tiercelin, J.J., Le Hérissé, A., Potdevin, J.L. and Le Gall, B. (2004) Hydrocarbon Potential of the Meso-Cenozoic Turkana Depression, Northern Kenya. II. Source Rocks: Quality, Maturation, Depositional Environments and Structural Control. Marine and Petroluem Geology, 21, 63-78. http://www.elsevier.com/locate/marpetgeo

[18] Tiercelin, J., Thuo, P., Nalpas, T. and Potdevin, J. (2009) Hydrocarbon Prospectivity in Mesozoic and Early Cenozoic Rift Basins in Central/Northern Kenya. AAPG In- 
ternational Conference and Exhibition, 10188, 10.

[19] Cheng, K.M., Wang, S.Q., Dong, D.Z., Huang, J.L. and Li, X.J. (2009) Accumulation Conditions of Shale Gas Reservoirs in the Lower Cambrian Qiongzhusi Formation, the Upper Yangtze Region. Natural Gas Industry, 29, 40-44.

[20] Wang, T.S., Geng, A., Li, X., Wang, H.J., Wang, Z.C. and Li, Q.F. (2011) A Prediction Model of Oil Cracked Gas Resources and Its Application in the Gas Pools of Feixianguan Formation in NE Sichuan Basin, SW China. Journal of Geological Research, 2011, Article ID 592567.

[21] Emerson, S. and Hedges, J.I. (1988) Processes Controlling the Organic Carbon Content of Open Ocean Sediments. Paleoceanography and Paleoclimatology, 3, 621-634. https://doi.org/10.1029/PA003i005p00621

[22] Vandenbroucke, M., Behar, F. and Rudkiewicz J.L. (1999) Kinetic Modelling of Petroleum Formation and Cracking: Implications from the High Pressure/High Temperature Elgin Field (UK, North Sea). Organic Geochemistry, 30, 1105-1125. https://doi.org/10.1016/S0146-6380(99)00089-3

[23] Jin, M.D., Cao, J., Shi, C.H., Zeng, W., Shen, C., Shi, K.L., Cheng, X.Y. and Tan, X.C. (2016) Hydrocarbon Origin and Reservoir Forming Model Research of Longwangmiao Formation, Moxi-Gaoshiti Area, Sichuan Basin. Petroleum, 2, 130-137.

[24] Safronova, N.S., Grishantseva, E.S. and Korobeinik, G.S. (2013) Hydrocarbon Gases (C1-C5) and Organic Matter in Bottom Sediments of the Ivankovo Reservoir on the Volga River. Water Resources, 40, 285-296.

[25] Zaghden, H., Tedetti, M., Sayadi, S., Serbaji, M.M., Elleuch, B. and Saliot, A. (2017) Origin and Distribution of Hydrocarbons and Organic Matter in the Surficial Sediments of the Sfax-Kerkennah Channel (Tunisia, Southern Mediterranean Sea). Marine Pollution Bulletin, 117, 414-428.

[26] Bjorlykke, K. (2010) Sequence Stratigraphy, Seismic Stratigraphy and Basin Analysis. In: Petroleum Geoscience, Springer, Berlin, 235-251. http://www.springerlink.com/index/10.1007/978-3-642-02332-3 https://doi.org/10.1007/978-3-642-02332-3_8 